\title{
Towards mutual understanding within interdisciplinary palaeoenvironmental research: An exemplary analysis of the term landscape
}

\author{
Frank Förster ${ }^{\mathrm{a}, \mathrm{b}, *}$, Ralph Großmann ${ }^{\mathrm{a}, \mathrm{c}}$, Martin Hinz ${ }^{\mathrm{a}, \mathrm{c}}$, Karina Iwe ${ }^{\mathrm{a}, \mathrm{c}}$, Hanno Kinkel ${ }^{\mathrm{a}, \mathrm{d}}$, \\ Annegret Larsen ${ }^{\mathrm{a}, \mathrm{e}}$, Uta Lungershausen ${ }^{\mathrm{a}, \mathrm{f}}$, Chiara Matarese ${ }^{\mathrm{a}, \mathrm{b}}$, Philipp Meurer ${ }^{\mathrm{a}, \mathrm{g}}$, \\ Oliver Nelle $^{\mathrm{a}, \mathrm{e}}$, Vincent Robin ${ }^{\mathrm{a}, \mathrm{e}}$, Michael Teichmann ${ }^{\mathrm{a}, \mathrm{h}}$
}

a University of Kiel, Graduate School "Human Development in Landscapes", Leibnizstr. 3, DE-24098 Kiel, Germany

${ }^{\mathrm{b}}$ University of Kiel, Institute of Classics, Leibnizstr. 8, DE-24098 Kiel, Germany

${ }^{\mathrm{C}}$ University of Kiel, Department of Pre- and Protohistoric Archaeology, Johanna-Mestorf-Str. 2-6, DE-24098 Kiel, Germany

${ }^{\mathrm{d}}$ University of Southern Denmark, Campusvej 55, DK-5230 Odense, Denmark

e University of Kiel, Institute for Ecosystem Research, Olshausenstr. 75, DE-24098 Kiel, Germany

${ }^{\mathrm{f}}$ University of Kiel, Department of Geography, Ludewig-Meyn-Str. 14, DE-24098 Kiel, Germany

${ }^{\mathrm{g}}$ University of Kiel, Institute of Art History, Wilhelm-Seelig-Platz 2, DE-24098 Kiel, Germany

${ }^{\mathrm{h}}$ Rome Department of the German Archeological Institute, Via Curtatone, 4 d, I-00185 Roma, Italy

\section{A R T I C L E I N F O}

Article history:

Available online 9 August 2013

\begin{abstract}
A B S T R A C T
The term landscape is a crucial term for a diversity of scientific disciplines researching the Quaternary each of which maintains different concepts and definitions. With increasing interdisciplinary research cooperation between disparate disciplines, a basis for communication has to be established. The aim of this paper is a) to survey an assortment of concepts and understandings of landscape within diverse disciplinary contexts and $b$ ) to explore the possibilities and usefulness of a common concept in an interdisciplinary palaeo-environmental research field, shared by scholars from the humanities and natural sciences alike. This comprises the disciplines art history, prehistoric archaeology, classical archaeology, ecology, geography, geology, and history. As a result, it can be stated that landscape is a cultural term: Landscapes are a cultural construct, and any landscape is the result of contemporary vision which is culturally influenced by the current context. Thus, landscapes are always shaped through today's construction of landscapes, independent from the discipline, and equally if in or for modern, or prehistoric times, and equally, if with or without humans.
\end{abstract}

(c) 2013 Elsevier Ltd and INQUA. All rights reserved.

\section{Introduction}

The term landscape is a crucial term for a diversity of scientific disciplines researching the Quaternary, each of which maintains different concepts and definitions. With increasing interdisciplinary research cooperation between disparate disciplines, a basis for communication has to be established. This includes an awareness of differences in understanding while using the same word (see introduction of Kluiving and Guttmann-Bond, 2012; Kluiving et al., 2012; Bebermeier et al. 2012). The aim of this paper is a) to

\footnotetext{
* Corresponding author. University of Kiel, Graduate School "Human Development in Landscapes", Leibnizstr. 3, DE-24098 Kiel, Germany.

E-mail address: ffoerster@gshdl.uni-kiel.de (F. Förster).
}

survey an assortment of concepts and understandings of landscape within diverse disciplinary contexts and b) to explore the possibilities and usefulness of a common concept in an interdisciplinary palaeo-environmental research field, shared by scholars from the humanities and natural sciences alike. The formulation of various facets of landscape might facilitate a better mutual understanding. The disciplinary contributions mainly focus on three issues: firstly, the term landscape is set within its hierarchy of technical terms from the respective discipline. Secondly, several parameters by which landscape can be described are named. Thirdly, the significance of human influence is given, to show its integration within the concept of landscape.

This paper is an extended and further developed version of the short paper published in the conference proceedings of the Landscape Archaeology Conference 2012 (Förster et al., 2012). It delivers 
disciplinary viewpoints with the aim of creating a combined notion of the concept of landscape, and challenging the thesis of Meier (2012) that the term is "acting as an envelope for anything".

\section{Etymology}

According to the OED, landscape is derived from the Dutch landschap as technical term for painters. The polysemous word landscape allows at least two readings in the English language: either the view or prospect of natural inland scenery is meant, or its painted or drawn representation within a picture or portrait is described. Both can be used in a generalized sense and extended in various figurative senses showing a tendency in either direction: on the one hand it is meant as a view or prospect of something, such as the object of one's gaze, a bird's eye view, or on the other hand as a sketch of a faint representation or depiction of something, which holds true across all readings whether visualized or verbalized.

The English word landscape can be split up into its root land and the derivational morpheme -scape. The basic meaning of land denotes, in the case of landscape (among other readings), most likely the "solid portion of the earth's surface, as opposed to sea, water" (s.v. OED). All other readings are not suitable; neither "ground, soil", nor "country", nor "owned property". The combining form -scape represents two possibilities: it means either a view or a picture, in both cases of a specific thing which is determined by the root element. Due to this broad variety of readings, landscape seems to be a comprehensive term for several concurrent derivative forms. Other compounds with the suffixoid -scape are, for example, cityscape, hardscape (man-made elements of landscape architecture), icescape, junglescape, mountainscape, mudscape, offscape (a distant view), roadscape, rockscape, seascape, snowscape, streetscape, townscape, and treescape (s.v. OED).

Other languages have similar terms, like the German Landschaft, the Dutch landschap ("as scenery and as the area under a particular regime of administration," Antrop, 2005, pp. 23 and 25), the Danish landskab, and the Swedish landskap. The respective terms in Italian (paesaggio), Spanish (paisaje), Portuguese (paisagem), and French (paysage, here as "homeland of those who created it" [Antrop, 2005, p. 23]) are even clearer in their origin: they share a root meaning land (país, pays, paese), supplemented by a similar derivational morpheme which denotes a relation to a place named by the root.

\section{Landscape within various disciplinary contexts}

The following chapters describe the term landscape from various disciplinary viewpoints, written by respective specialists from the particular fields. They narrow down their particular concept to what is essential for them in defining the term landscape. Thus, it is obvious that each chapter differs in philosophical depth and elaboration.

\subsection{Art history}

Various disciplines agree that reality is composed not only linguistically, but also visually from time immemorial. The world is the image of the world. Art history often deals with images of something. The reason is that most recent and historic pictures are objective and have a reference to reality, regardless of whether they are artistic compositions or not. Landscape images are representations of landscapes, for example as drawing, painting, or photography. Representation means that the impression or illusion of a landscape evolves in the mind of the observer, although it should be clear that it is a two-dimensional object made of some colored marks. Surprisingly, the relation to reality is merely a secondary level of meaning, regardless of whether it is an image of a real or fictitious landscape (see also Gombrich). The real object (German Ding an sich, see Kant, 1783, pp. 62f.) is only of secondary importance; more important is its perception as demonstrated within images. Wuketis (2010) comprises anthropological and cultural foundations of the "visualistic turn."

In contrast to a natural scientific, materialistic approach, most art historians assume implicitly that landscape is something to be looked at. Landscape does not exist on its own, but rather needs a perceiving subject. Landscape comes into being through a constructive act, and only in the imagination of an observer. This is not meant to imply that there is no physical foundation for landscape. Rather, the notion of a distinct and conceptualized "something" evolves in the imagination, and structures and elements within an environment are likewise perceived as coherent (and interdependent), so that it is called a landscape, being distinguishable from other landscapes. The criteria for coherence and distinctive features can be quite different; for example the same geographic area can be called a "periglacial plain" or a "romantic heath." Hard (1964) elaborates on geography as arts.

Art history deals with a two-fold act of construction: the dichotomy of "perceiving subject - landscape" equals the dichotomy of "perceiving subject - landscape image". Several landscape paintings and pictures make this visible by showing obviously contemplative people standing with their backs to the observer, like in landscape paintings by C.D. Friedrich. Next to "man in landscape" there is a dialectical "man and landscape" at the same time. These paradigms are seldom picked out as a central theme within reference literature concerning landscape paintings. Most contributions do not ask what landscape is, but begin with the image itself, even though there are counter-examples, as an essay about landscape painting by Max Friedländer proves: "Land is the surface of the earth or a part of it, but landscape is the face of the land, the land in its impression on us. [...] The land is the 'real object', landscape the 'appearance'. The peasant knows the land that he is working, that nourishes him, he looks up to the sky where light and rain comes from, however, the landscape does not affect him; enjoying the view cannot emerge where poverty and exploitation rule." (Friedländer, 1963, pp. 27f., translation by the authors) Simmel (1913) already focused on same the issues. Friedländer anticipates the emphasis on the aesthetic distance with this differentiation, which is the core theme of a most influential essay about landscape by the philosopher Joachim Ritter (1974). The increasing separation between town and country, man and nature in modern times made the substantiation of the concept landscape in today's sense possible. The prerequisite of aesthetic observation lies in an intentional perception, in making aware of a vis-à-vis. Therefore, the concept of as defined today landscape is genuinely aesthetic. The etymology shows that this development of this meaning coincides with the development of autonomous landscape painting in the early 16 th century. This process is sketched in a broad study combining art history with etymology, psychology and philosophy. Fechner (1986) delivers not only a historical outline, but also a prolific critique of Ritter (1974). A recent book on the history of landscape painting comes to the same conclusion (Büttner, 2006). The etymology is again the inspiration for a (slightly weak) explanation of art historic categories. Implicitly, however, it becomes clear that the dichotomy between observer and landscape is constitutive not only for art historic reflections, but is also relevant beyond disciplinary boundaries (see Hard, 1995); it is a fundamental principle for recent scientific thinking.

\subsection{Prehistoric archaeology}

The concept of landscape in prehistoric archaeology is closely connected with the term cultural landscape; it focuses on the 
relationship of past peoples with environments. In general it is addressed through studies in the broad field of landscape archaeology, which in Germany is especially related to Siedlungsarchäologie (settlement archaeology); a term that often was, and partly still is, used synonymously. Landscape archaeology is used for very different approaches which have in common that they investigate the network of relationships of situations that are located in a specific space. These relationships can consist of natural/environmental, social, cultural or spiritual/symbolic influences, and accordingly an interpretation of "landscape archaeology" exists for each of these kinds of relationships.

According to Bender (1993, p. 1), “landscapes are created by people - through their experience and engagement with the world around them $[\ldots]$ The landscape is never inert, people engage with it, appropriate and contest it. It is part of the way in which identities are created and disputed." In a systems theoretical point of view the differences between landscapes, and by extension landscape archaeologies, lie in what is referred to as a system and what forms the environment of that system. If the ethnic group is the system under investigation, then other ethnic groups are the environment, the landscape. When the socioeconomic system is in focus, it is the natural surrounding that is attributed as landscape; when it is the symbolic system, it is the landscape of symbolic meaning that is investigated by landscape archaeology.

In Germany, the very beginning of landscape archaeology is linked to Rudolf Virchow, who started an inventory of monuments at the end of the 19th century (see Kossack, 1999) resulting in the creation of the research field Siedlungsarchäologie. In this approach, prominently pursued by Kossinna (1911), a cultural-historical perspective was taken, where ethnic groups as "cultures" were thought to constitute the landscape.

This process led to the establishment of the subject of prehistory while regarding the genesis and development of the Siedlungsräume (settlement space) of certain groups (Smolla, 1979/80). Engel (1930) already used the term settlement archaeology in combination with nature and humans; questions about ecological conditions arose in addition to this. Researchers left behind the ideologically influenced notion of the term after the Second World War. Eggers (1951) tried to start a discussion with a new journal which focused on the central method of settlement archaeology (cartography). Jankuhn (1977) concentrated on the research of settlement activities in connection with settlement history. Settlement history is closely connected to settlement archaeology, but geography, history of vegetation, subsistence strategy and questions of social matters are also involved in the latter. The approach by Janssen (1988) centered on interdisciplinarity; methods and questions regarding the formation and development of settlements and settlement landscapes were in the foreground.

The aim of these approaches was to describe the processes and history of settlement. Individual Siedlungskammern ("settlement clusters") were investigated; their natural surroundings were taken as the background and driver for socioeconomic processes, while interaction with the natural surrounding itself played a minor role. This kind of analysis was freed from ideological burden, but at the price of the total abundance of a cultural perspective. This is in line with the developments in the Anglo-American concepts originating from the processual or new archaeology.

According to Gramsch (2003), landscape archaeology focuses on "Raum" (space) and culture-nature relations. The economic, sociopolitical and societal functions of a landscape are part of the interpretation. In order to reconstruct the prehistoric cultural landscape, Lüning (1997) described the methods of landscape archaeology. Landscape archaeology encompasses different fields of investigation, such as the archaeology of settlement, economy, social systems and ecology. Archaeologists make use of methods and sources from both the humanities (historical sources) and natural sciences (such as survey, geographical information systems, geomagnetics, aerial photography, radiocarbon dating, and soil and vegetation analysis). The aim of landscape archaeology is to reconstruct the whole system of human activities, for example agricultural and mine production, and the exchange and trade system represented by settlements within their social structure (Lüning, 1997, p. 280).

In the strict sense, today's discussion in landscape archaeology is strongly influenced by postprocessual and phenomenological approaches (for example advocated by Christopher Tilley or Timothy Ingold). In this regard, the symbolic and ritual aspects and meanings of landscape gained importance. In the German scientific community, landscape archaeology is often specifically used to distinguish from the settlement archaeology that was primarily oriented towards an investigation of the so-called natural environment and its relations to human activities. One could provocatively ask, given that archaeology is the study of man as cultural being and that man makes an environment into a cultural unit merely by his or her appearance, if there can be such thing as a natural landscape in archaeological studies. Landscape is now often regarded as the mental and cognitive process by which man defines and shapes space in order to "tame" it (Thomas, 1991, p. 30). This space encompasses the physical world, other humans and relations with them, as well as meaning, located and distributed over space. A specific mental map or image influences the way people interact in and with this space. Yet with such a holistic understanding certain methodological difficulties for operationalization and reasoning from an, at best, sketchy database emerge. For this reason, different studies tend to either stick to the "natural surrounding" as the background for a processual interpretation, or thematize the subjective influence of the landscape on individual reasoning, with the difficulties that an intersubjective or even objective version of the significance of meaning is hard to reach. Nevertheless, this consciousness of a broad term landscape has promoted archaeological reasoning to a new and more complex understanding of the human past (see Kluiving and GuttmannBond, 2012 passim).

\subsection{Classical archaeology}

Landscape Archaeology is a sub-discipline of archaeology, while simultaneously being a supra-discipline, which bridges archaeology to a number of related fields. Scientific approaches in classical archaeology tended for a long time to depend particularly on national research traditions and the historically defined role of the discipline, which differed between countries. As case studies, the role and conceptual frame of landscape archaeology in the Italian and German traditions will be discussed.

The awareness of the crucial role of a particular landscape for the proper understanding and perception of ancient monuments goes back a long way, as it was realized early on that sites have to be perceived with respect to their original landscape context. Otherwise theoretical concepts and thorough methodological discussions of approaches to landscape are seldom discussed in detail.

In Italy the discipline of ancient topography (topografia antica) is well-established within the framework of Archaeology at university institutes. The roots of the Italian tradition reach back to researchers of local history, humanists and artists, Italians and travelling foreign scholars, who described or depicted standing Roman remains (Cambi and Terrenato, 2006, pp. 13-21; Quilici and Quilici Gigli, 2004, pp. 10-14). Early topographers were particularly interested in identifying sites which were mentioned by ancient authors and in improving the understanding of local history. The monuments were seen as remains of a long gone, glorious past 
which was still admired. Standing building structures were perceived as the most interesting aspect of ancient landscapes. In particular, from the second half of the 19th century onwards, due to the initiative of single persons (such as Lanciani, T. Ashby and later on Lugli), detailed archaeological maps were created with the aim of reconstructing ancient settlement patterns. A particular focus of this research was on the Campagna Romana; the countryside surrounding Rome, where remarkable traces of Roman buildings were preserved before the rapid transformation of rural central Italy in the 20th century.

A separation of ancient topography and classical archaeology on the one side from natural scientific approaches to past landscapes on the other started quite early in the history of research (Cambi and Terrenato, 2006, p. 29), leaving ancient topography to focus almost exclusively on the remains of the cultural landscape. In particular, geo-archaeology has been regarded by some researchers with skepticism until recent times (Santoro Bianchi, 1998, p. 830f.). Paleo-ecological studies are appreciated, but are generally not perceived as an integral part of Landscape Archaeology, but rather as a separate discipline (Santoro Bianchi, 1998, p. 828) and it was pointed out that the historic reconstruction of past landscapes should always be the primary scope of landscape archaeological research (Morigi, 2009, p. 366). Recent interdisciplinary developments are therefore seen more as a distraction from the original scope (Morigi, 2009, p. 365). From the 1990s onwards, interest in Landscape Archaeology intensified in Italy, stimulated by advances in GIS, expressed in the creation of archaeological maps in several regions. Theoretical discussions are rare in recent Italian classical archaeology (Cambi and Terrenato, 2006, p. 41). Observing the separation of ancient topography and traditional classical archaeology in Italy, it is noteworthy that the latter had, for long time, a primary interest in ancient art and architecture, in the classicist-romantic tradition of Winkelmann (Athanassopoulos and Wandsnider, 2004, p. 1-2).

The origins of topographic archaeological research in what was later to become German classical archaeology, reach back at least to the journeys of German elites, who, like the upper class of many European countries, travelled on the "grand tour" to Italy as an important part of their education in the late 17th, 18th and 19th centuries (Salvagni and Fratarcangeli, 2012). Taking this as a starting point, the discipline called Historische Landeskunde was established, which might be roughly translated as landscape history (for an extensive discussion of the role of landscape archaeology in German classical Archaeology see Teichmann, 2010). This field of research was, from its origins onwards, already undertaken as an interdisciplinary approach combining geography, archaeology and history, with additional contributions from other disciplines such as epigraphy and ethnological studies of contemporary societies (Gehrke, 2009, p. 39).

A major break for these approaches can be observed after the First World War as German classical archaeology undertook a major conceptual shift: the prevailing positivism, formerly a key element of research, was questioned. While "Mensch und Raum" (Man and space) had previously been a priority on the research agenda, "Der schöne Mensch im Altertum" (human aesthetics in antiquity) now played a more pronounced role (Gehrke, 2009, p. 40). Having experienced the ideological abuse of archaeology by the fascist government of the mid-20th century, the discipline of classical archaeology widely retreated from theoretical discussions and more descriptive approaches were chosen. Landscape mattered in classical archaeology in particular as the backdrop for the development of specific art and architecture styles, coining the term "Kunstlandschaft." Parallel to this art historical approach, settlement archaeology was conducted; building mainly on a methodological framework developed in Pre- and Protohistoric Archaeology (see Section 3.2). The work of Kossinna (1911) needs to be mentioned here (Lang, 2002, p. 252). The ideas of his settlement archaeology were based on the definition of certain cultural groups by the typological similarity of their artifacts. This research was of some importance in the framework of the National Socialist ideological concept and was therefore criticized significantly in recent academic debate (Lang, 2002, p. 252). A further development and methodological extension can be attributed to Jankuhn (1977, 1979), who included, among other aspects, resources and economical potential as parameters. The last few decades have seen the eclectic reception of developments from the Anglo-American Archaeology. Developments in the so-called "New Geology" influenced spatial concepts of the "New Archaeology." A major boost can be seen in the spread of so-called "intensive surveys," which aim at the methodological sampling of a cultural landscape.

With respect to pre- and protohistoric archaeology, there is often a kind of delay in the application of methods. In this sense, elements rooted in processual archaeology are still applied today, while much post-processual thought has not been of relevance (Snodgrass, 2009, pp. 353f.).

Regarding the general impact of post-processualism on the archaeology of classical archaeology within and besides the German tradition, while there are some processual British approaches to Mediterranean landscapes, pure post-processual discussion is primarily restricted to prehistoric archaeology north of the Alps. Suggestions for a fusion of processual and post-processual archaeology are rare, but were also proposed for classical antiquity (Witcher, 1999; Launaro, 2004). These authors emphasized that antiquity might be particularly suitable for experimenting with post-processual approaches, as images and written sources provide us with a clearer impression of landscape perception than is the case for illiterate prehistoric societies, where considerations regarding landscape perception have to be more speculative (Launaro, 2004).

If we try to conclude the review of the German classical archaeological approaches to landscape, we can state that landscape is perceived in classical archaeology as a cultural landscape, which is nevertheless not defined in detail. Landscape is the result of human action and forms a contrast to the towns which were crucial for the town-based societies of Greek and Roman antiquity. In a historical perspective, landscape already played an important role in the early days of research, lost importance from the 1920s onwards in the German tradition, and was revived in recent times.

\subsection{Ecology, palaeoecology}

Ecological systems are complex, dynamic systems formed by the retro-active interactions of biotic and abiotic components (Odum, 1994; Meyers, 2009; Dawson et al., 2010). Those components and their processes of interaction are structured in space and time with hierarchical patterns (Levin, 1992; Burel and Baudry, 2000; Chapin et al., 2002). In this frame, the notion of landscape corresponds to a specific hierarchical level of the spatiotemporal structure of ecological systems for the various approaches of the ecological science (Fig. 1). Landscapes in ecology are identifiable entities, definable in time and space. A major difference to most of the other definitions of landscapes is the fact that, from the point of view of an ecologist, landscapes have their own components and processes, inducing their own structure, organization and functioning, allowing them to exist even without humans and human perception.

The landscape level of ecological systems includes several lower levels of structuring, organization, and functioning, like ecosystems, and are themselves included in an upper level of structuring, organization, and functioning of ecological systems, for example in 


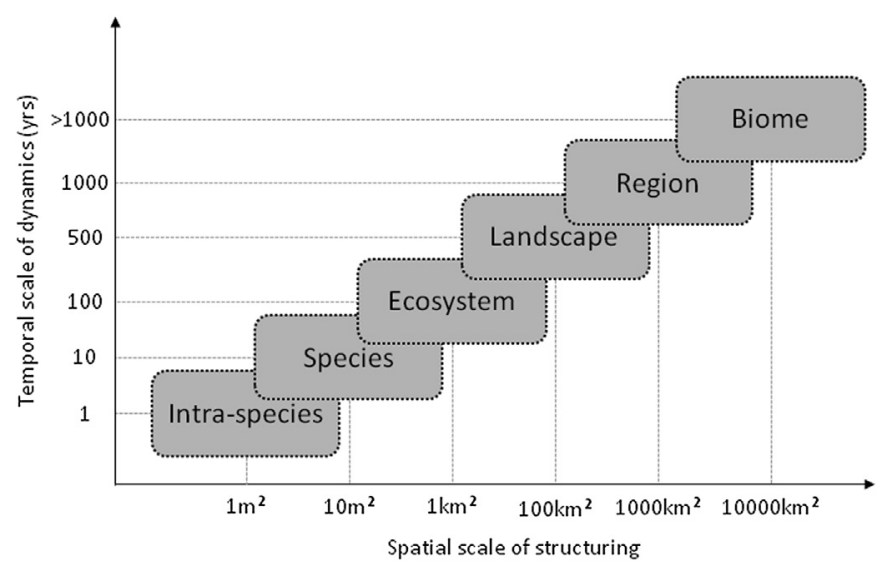

Fig. 1. Linear representation of the spatiotemporal scales of ecological system structuring and dynamics.

a regional matrix (Aronson and Le Floc'h, 1996). Landscapes present their own characteristics, with specific components and processes. Such parameters and processes can be measured and quantified, at least in parts, as far as current scientific knowledge allows, such as through species richness (e.g. Dauber et al., 2003; Steiner and Köhler, 2003), biodiversity (e.g. Waldhardt, 2003), genetic flux between populations (e.g. Ao, 2009), biogeochemical flux, or trophic chains etc. Moreover, one important feature of landscape scale is the role of human populations (Burel and Baudry, 2000), notably as disturbance for ecological processes, inducing heterogeneity of landscape components. Indeed, past and on-going human activities (e.g. resource usages, urbanization, etc.), generally induced changes at the scale of ecosystems. Such changes are by default included at the landscape level, by including a multitude of ecosystems presenting various stages of spatiotemporal dynamics, forming a mosaic of ecological systems. Thus landscapes represent, most of the time, a considerable level of habitat and biological diversity (Blaschke, 2006). Therefore, during the last decades the landscape level has been increasingly considered by scientist and managers. Indeed, the landscape level appears crucial in management planning since it includes meta-populations which allow the development of conservation/restoration strategies for the sustainable management of biological diversity (e.g. Ticktin, 2005), in compromise with local human activities (e.g. Heard et al., 2012).

\subsection{Geography}

The concept of landscape has been discussed as key term since the beginning of the 20th century. Passarge (1919) defined natural landscapes as a "district which so far as possible represents a unit according to its climate and vegetation cover, modelling of the surface, geological structure and soil. Generally, all mentioned characteristics do not coincide; some must however agree to unify, if a landscape is to result" (Fairbridge, 1968, p. 629). Passarge (1921) continues that landscapes cannot be seen as a "single oneness," but rather can be broken down to "sectional landscapes" according to relief forms, waters, soils and vegetation cover. Fairbridge (1968) concludes that even though landscape has always been defined as an entity, geographers have usually chosen which part of the landscape they research; some focus on physical properties and others on more social aspects or time. The concept of landscape is often mixed up with region, but in the hierarchy of terms, landscape describes an integrated spatial view, following region and zone in size. A landscape features the same regional characteristics as its adjacent landscapes, but differs in factors like topography, drainage, land-use, type of settlement etc. Importantly, although landscape is a geographical unit of relatively small size, it is large enough to be a representative section of the earth's surface, with anything smaller no longer being representative. This might be the reason for its popularity among geographers as a powerful concept. This richness of detail leads to the conclusion that each landscape is unique, albeit belonging perhaps to a landscape type that combines other individual examples. This uniqueness becomes especially strong when human aspects are integrated into the concept.

\subsection{Geology}

The opening sentences of Charles Lyell's "Principles of Geology" clarify that geologists perceive landscape as a result of external and internal forces acting on the structuring of the surface of the earth: "Geology is the science which investigates the successive changes that have taken place in the organic and inorganic kingdoms of nature; it enquires into the causes of these changes, and the influence which they have exerted in modifying the surface and external structure of our planet." (Lyell, 1830, p. 1) The birth of modern geology in the 18th century is linked to James Hutton, who investigated geologic settings while clearing and draining his farmland. Besides inspections of various compositions of rocks, he observed the landscape with respect to processes that might have formed it. It led him to the concept of uniformitarianism; assuming that natural laws and processes acting on the earth now, acted likewise a long time ago.

Although frequently used, the term landscape (also palaeolandscape) is not clearly defined in geology. Most likely, geologists have a similar definition of landscape to physical geographers and use it in describing geomorphologic features encountered in a certain environment. However, in contrast to geographers, geologists perceive a mountain range as the result of tectonic forces and as an ideal place to study ancient rocks. Moreover, geologists use landscapes as analogues for past environments and relate observed processes in modern landscapes (e.g. erosion, or sedimentation) to past processes according to actualistic approaches. Thus, their process-oriented approach requires developing a four-dimensional view on landscapes, not only looking at the surface and the depths below, but also back in time.

From a geocentric viewpoint, geologists would argue that factors which shape the landscape are the geological forces of tectonics and erosion. More recently, the discussion about landscapes in geological terms has reached a next level, as the debate on the "Anthropocene" has started. Within this context it is discussed when, and to what extent, humans became agents in the transformation of landscapes, thus not only leaving distinct geological traces (that might still be visible in millions of years from now), but also altering the earth system towards another state (Zalasiewicz et al., 2010). Within this context it has been shown, that modification of the landscape began early in the Holocene with the rise of agriculture, which led to a massive land use by the Mid Holocene (ca. 4 ka BP) that had a potential effect on the global carbon cycle and thus stabilized the climate, which otherwise would have become colder during the course of the Holocene (Kaplan et al., 2011).

\subsection{History}

As historians, we can approach the concept of "landscape" through two different perspectives. If we just address history as the "study of past events, esp. human affairs" (s.v. OED), we would instinctively admit that landscape as "natural landscape," without human presence, does not interest us. In that way, summarizing concepts which have still been expressed, landscape is to be 
considered just as the interaction of the predominant anthropogenic element and non-anthropogenic influences (Bernard and Sattler, 1997, p. 102).

On the other hand, if we consider the "history of ideas", which deals with the expression, preservation and change of human ideas in time (Lovejoy, 2009, p. 3), we can also address as historians landscape as the natural landscape, which we call environment. Such a research study could determine which of the modern concepts of landscape were taken into consideration in Antiquity, the Middle Ages, Modern times and why, as well as using linguistic analysis to determine which terms the different sources use to express different concepts. However, human beings did not focus so early on the natural landscape: this notion was first conceptualized by Alexander von Humboldt in the 18th Century (Humboldt, 1849; Kwa, 2005). The ancient Greek conception of space was founded on the belief that the natural landscape determined the anthropized space, as the environment transformed and adapted either to meet the needs of humans or thanks to human activity (Bearzot, 2010). This idea legitimated human appropriation of the environment and its exploitation. We can express what we refer to through Aristotle's words when he writes that "plants exist for the sake of animals, and that the other animals exist for the sake of man" (Pol. 1256b16-8), and, again that if "nature makes nothing either incomplete or to no purpose, it must be that nature has made all of them for the sake of man" (Pol. 1256b20-2; see also Ph. 194a35; 200b3).

Coming back to the first perspective, we give to landscape, as the interaction of human and natural phenomenon, a social-economic and cultural-political significance and come to see how the two elements influenced (and influence) each other. Each man in history has the possibility of modifying his available landscape, theoretically speaking, and he has done and does so in many different ways, depending on two main factors. The first one, which is the starting point of any human action, is his necessities; the second one, which influences the possibility of acting practically, is his social status. As a simple example concerning the first point, we can see how men began planting seeds for an assured food supply during the Neolithic agricultural revolution in the 10th millennium BC (Greene, 1999, p. 5), building property lines to protect supplies. Concerning the second point, we know that from the time of the Ancient Near East onwards, particularly in Assyrian and Persian times, kings had the full control of land and water, planned and optimized the use of the resources, looked for these necessary materials, which were not available in their reign (see e.g. Beaumont et al., 1976, pp. 88-92; Briant, 2002, pp. 804-12; Wuttmann and Marchand, 2005). Otherwise they structured landscape to be the mirror of their political power by having wonderful palaces built and detailing on reliefs how many people were subjected to them (Briant, 2002, 17-23; Guaitoli and Rambaldi, 2006); nobody else could have so great an influence on the landscape as the king.

Considering man's action on the landscape, our research would deal with giving answers to some typical questions, such as which means human beings used to change and structure their landscapes and why. On the other hand, the landscape as a sum of natural elements, as vegetation and climate, has always had a great influence on human beings' lives. Even though historians deal more frequently with political mobility, such as migrations and exiles, we cannot deny that environmental and climatic changes are factors that have forced, and continue to force, people to move and migrate. Climate changes are expected to trigger growing population movements within and across borders, as a result of such factors as increasing intensity of extreme weather events, sea-level rise and acceleration of environmental degradation. In addition, "climate change will have adverse consequences for livelihoods, public health, food security, and water availability. This in turn will impact on human mobility, likely leading to a substantial rise in the scale of migration and displacement" (IOM, 2011). With regards to this aspect, the question would be which environmental factors influenced peoples and which kind of changes they brought about for human life (see the conclusion in Kluiving and Guttmann-Bond, 2012).

Focusing on, understanding and explaining the interactions between people and landscapes can be a difficult task. The complexity of the interaction between people and landscape is due to the fact that both of them undergo two kinds of ever-changing developments.

The first, which we call A-type development, is an individual one: Humans as well as the environment change and develop independently. An example would be that people modify their political, social, economical structure, such as their way of thinking (their culture in its extensive sense, as "that complex whole which includes knowledge, belief, art, morals, law, custom and any other capabilities and habits acquired by man as a member of society", Tylor, 1924, I-II, I, p. 1) irrespective of environmental factors. On the other hand, environmental changes can occur due to factors which have nothing to do with human will. So, environmental changes occur as a result of natural processes and human changes occur as a result of anthropogenic factors.

However, as we have briefly illustrated, many changes of the one kind are brought about by the other kind: Environmental changes can occur as result of human processes as well as human changes as result of natural factors. We call these changes B-type development. An example would be that the scale of planetary changes induced by human activities is clearly evident in the modification of the physical landscape. Since the 18th century, the planet has lost 6 million $\mathrm{km}^{2}$ of forests, an area larger than Europe (Clark and Clark, 1989). Even though the exact degree of such an impact is unknown, it is undeniable that humans impact the earth's biodiversity and caused the extinction of many species (May, 1988).

What is more, each change of the one kind, the A-type as well as the B-type, can bring about a second-level development of the other. Second-level changes may happen when human conditions, which changed due to environmental factors, re-change the environment, or when natural landscape, which developed through human actions, re-changed the anthropogenic factor. An example could be that humans bring pollutants directly into the air (due to burning fossil fuels, emissions from industries and manufacturing activities, household and farming chemicals). The resultant pollution of the air has an influence for health, survival and activities of human beings (e.g. Pinkerton/Joad, 2006; Eckhardt et al., 2013).

We can clarify the different kinds of interaction between people and landscape in the following way ( $H=$ human beings structured in a society; $L=$ landscape as the combination of natural factors):

A-type changes:

1. $H \rightarrow H^{1} \rightarrow H^{2} \rightarrow H^{3}$

2. $L \rightarrow L^{1} \rightarrow L^{2} \rightarrow L^{3}$

B-type changes:

$H L \stackrel{L H}{\rightarrow} H^{1} L^{1} \stackrel{L H}{\rightarrow} H^{2} L^{2} \stackrel{L H}{\rightarrow} H^{3} L^{3}$

Second-level changes:

$H \rightarrow L^{1} \rightarrow H^{2} \rightarrow L^{3}$

$L \rightarrow H^{1} \rightarrow L^{2} \rightarrow H^{3}$

In conclusion, an historians' approach to the landscape includes:

- Dealing with the previously illustrated complexity of the interaction between human factors and natural ones and 
researching in what way they have been in contact and had influence on each other.

- Searching in past sources for signs (written documents, archaeological evidence etc.) of human interest in landscape and of a conscious perception of all its different meanings and concepts.

\section{Discussion and conclusions}

The term landscape is of crucial significance within a wide range of disciplines. The word landscape itself is of two-fold meaning: it either means a view of natural inland scenery, or its visual or verbalized representation. The various disciplinary meanings of landscape seem to mirror these two readings. Yet the term is not only adapted, but also broadened with respect to discipline-specific needs.

Art historians use landscape either as artistic genre or as construction of nature, shaped within the mind of an observer. The natural scientific perspective considers landscape as a certain level of spatial reality, by naming particular factors which shape it. On the one hand, these are quantifiable parameters (or processes) like species richness or biodiversity in ecology, or topography, drainage and land-use in geography. On the other hand, human influence is often part of the definition of landscape, as can be seen by its socioeconomic and cultural-political significance in historical analyses or the study of settlement types in geography. Additionally, the influence of humans on landscape also affects definitions within other disciplines, as can be seen in classical as well as prehistoric archaeology. It seems as if the concept of a "dynamic space of social, cultural, and ecological significance, which develops interactively with the human societies occupying it" (GS, 2007) is functional enough for our purpose. However, the human influence proves to be essential in terms of the narrow viewpoint of our own particular concept, because human development within landscapes is a substantial part of our research projects. Either human influence is essential, because it is present within the discipline itself and thus an integral part of all definitions and research. Or human influence is part of the definition although not explicitly needed. Since humans tend to shape nature in terms of their own ideas, the differentiation between natural landscape and cultural landscape becomes evident here. However, even if humans are no part of the definition of landscape or ecology, they are nevertheless an integral part, even within disciplines like geology, because nature is observed from humans' viewpoints and methodologies, and objectively described (by research based on fieldwork and studies in archives and laboratories) with quantifiable, but nevertheless human-defined features. It is thus still shaped within the mind of an observer, as defined in art history.

Consequently, landscapes are always shaped through today's construction of landscapes, whether in or for modern or prehistoric times, and equally, whether with or without humans. Incidentally, it can be stated that landscape is a cultural term. Independent from the discipline, the semantic and pragmatic connotations of the term are influenced by the concrete cultural context of the particular interpreter. Therefore, this relationship is also plausible for prehistoric times and the prehistoric interpreter of landscape (in case our concept of landscape is at all transferable to prehistoric situations). Landscape is therefore a hermeneutic construct, and understanding past landscape concepts is always a subject to double hermeneutics (Giddens, 1987, 20).

As a common basis of understanding this works as a conceptual compromise. Though all are satisfied with it, each singular researcher is aware that the overall concept does not comprise every detail of the individual disciplinary approach. However, do we need such a compromise to work together sufficiently? Or can we do interdisciplinary research successfully without defining common terms and acknowledging a difference in definition and see it as a basis for future research questions?

We think that it is essential to find a conceptual compromise for common grounds of communication within specific research projects concerning important terms. Having said that, we conclude that momentarily it seems impossible to find a common definition where every aspect of the involved disciplines' concepts is included. Such an unachievable attempt would rather hinder collaboration. From this follows that the concept of landscape is not "acting as an envelope for anything," (Meier, 2012, p. 504) but as something which is put into the specific envelope of a research group. Only from a distant viewpoint does the diversity of projects and disciplines seem to merge the concept of a crucial term into a confusing "anything".

Thus, the definition of landscape as the "total character of an area of the Earth," as ascribed to Alexander von Humboldt" (Schenk, 2001, vol. 17, p. 619; Schenk obviously subsumes Humboldt's (1849) "Aspects of Nature" [“Ansichten der Natur,"]) does not seem to fulfill our demands in a sufficiently comprehensive manner.

Any research project highlighting landscape should try to find a conceptual compromise as a basis for interdisciplinary collaboration - and has to consider other approaches as well, not only those of its own discipline. It is the research project which "makes" the (academic) landscape, and not a theory "a priori" which is superimposed on the respective research question.

\section{Acknowledgements}

The authors would like to thank Nicole Taylor (University of Kiel) for proof-reading.

\section{References}

Antrop, M., 2005. Why landscapes of the past are important for the future. Landscape and Urban Planning 70, 21-34.

Ao, P., 2009. Global view of bionetwork dynamics: adaptive landscape. Journal of Genetics and Genomics 36, 63-73.

Aristotle: Pol. $=$ Politics, Ph. $=$ Physics

Aronson, J., Le Floc'h, E., 1996. Hierarchies and landscape history: dialoguing with Hobbs and Norton. Restoration Ecology 4, 327-333.

Athanassopoulos, E., Wandsnider, L., 2004. Mediterranean landscape archaeology past and present. In: Athanassopoulos, E., Wandsnider, L. (Eds.), Mediterranean Archaeological Landscapes: Current Issues. University of Pennsylvania Museum of Archaeology and Anthropology, Philadelphia, pp. 1-13.

Bearzot, C., September 2010. "Storia dell'Ecologia" e "ecologia storica". Uomo e ambiente nel mondo antico. Rivista della Scuola Superiore dell'Economia e delle Finanze. http://rivista.ssef.it.

Beaumont, P., et al., 1976. The Middle East: a Geographical Study. Wiley, London.

Bebermeier, W., Hebenstreit, R., Kaiser, E., Krause, J. (Eds.), 2012. Landscape archaeology. Proceedings of the International Conference Held in Berlin, 6-8 June 2012. eTopoi - Journal for Ancient Studies vol. 3 (Special Volume).

Bender, B., 1993. Landscape, Politics and Perspectives. Berg, Oxford.

Bernard, S., Sattler, P., 1997. Vor der Tür: Aktuelle Landschaftsarchitektur aus Berlin. Callwey, München.

Blaschke, T., 2006. The role of the spatial dimension within the framework of sustainable landscapes and natural capital. Landscape and Urban Planning 75, $198-226$.

Briant, P., 2002. From Cyrus to Alexander. A History of the Persian Empire. Eisenbrauns, Winona Lake (Original: Histoire de l'Empire Perse. De Cyrus à Alexandre. Fayard, Paris 1996).

Burel, F., Baudry, J., 2000. Ecologie du paysage: Concepts, méthodes et applications. Tec \& Doc, Paris.

Büttner, N., 2006. Geschichte der Landschaftsmalerei. Hirmer, München.

Cambi, F., Terrenato, N., 2006. Introduzione all'archeologia dei paesaggi, eighth ed. Nuova Italia scientifica, Rome.

Chapin III, F.S., Matson, P.A., Mooney, H.A., 2002. Principles of Terrestrial Ecosystem Ecology. Springer, New York.

Clark, D.B., Clark, D.A., 1989. The role of physical damage in the seedling mortality regime of a neotropical rain forest. Oikos 55, 225-230.

Dauber, J., Hirsch, M., Simmering, D., Waldhardt, R., Otte, A., Wolters, V., 2003 Landscape structure as an indicator of biodiversity: matrix effects on species richness. Agriculture, Ecosystems \& Environment 98, 321-329.

Dawson, T.P., Rounsevell, M.D.A., Kluvankova-Oravska, T., Chobotova, V., Stirling, A., 2010. Dynamic properties of complex adaptive ecosystems: implications for the sustainability of service provision. Biological Conservation 19, 2843-2853. 
Eckhardt, S., Hermansen, O., Grythe, H., Fiebig, M., Stebel, K., Cassiani, M., Baecklund, A., Stohl, A., 2013. The influence of cruise ship emissions on air pollution in Svalbard: a harbinger of a more polluted Arctic? Atmospheric Chemistry and Physics Discuss 13, 3071-3093.

Eggers, H.J., 1951. Die vergleichende geographisch-kartographische Methode in der Urgeschichtsforschung. Archaeologia Geographica 1,1-3.

Engel, C., 1930. Bilder aus der Vorzeit an der mittleren Elbe. Ein Heimat- und Volksbuch für den Regierungsbezirk Magdeburg und seine Grenzlandschaften. A. Hopfer, Burg bei Magdeburg.

Fairbridge, R.W. (Ed.), 1968. The Encyclopedia of Geomorphology. Reinhold, New York.

Fechner, R., 1986. Natur als Landschaft. Zur Entstehung der ästhetischen Landschaft. Lang, Frankfurt a. M.

Förster, F., Großmann, R., Iwe, K., Kinkel, H., Larsen, A., Lungershausen, U., Matarese, C., Meurer, P., Nelle, O., Robin, V., Teichmann, M., 2012. What is landscape? Towards a common concept within an interdisciplinary research environment. eTopoi - Journal for Ancient Studies, Special Volume 3, 169-179.

Friedländer, M.J., 1963. Die Landschaft (1st edition 1947). In: Friedländer, M.J. (Ed.), Über die Malerei. Bruckmann, München, pp. 26-125.

Gehrke, H.-J., 2009. Historische Landeskunde. In: Borbein, A.H., Hölscher, T., Zanker, P. (Eds.), Klassische Archäologie. Eine Einführung, second ed. Reimer, Berlin, pp. 39-51.

Giddens, A., 1987. Social Theory and Modern Sociology. Polity Press, Cambridge.

Gombrich, E.H., 1967. Kunst und Illusion: Zur Psychologie der bildlichen Darstellung. Phaidon, Köln.

Gramsch, A., 2003. Landschaftsarchäologie - ein fachgeschichtlicher Überblick und ein theoretisches Konzept. In: Kunow, J., Müller, J. (Eds.), Symposium Landschaftsarchäologie und Geographische Informationssysteme - Prognosekarten, Besiedlungsdynamik und Prähistorische Raumordnungen. Brandenburgisches Landesamt für Denkmalpflege u. Archäologisches Landesmuseum, Wünsdorf, pp. 35-54.

Greene, K., 1999. V. Gordon Childe and the vocabulary of revolutionary change. Antiquity $73,97-109$.

Guaitoli, M.T., Rambaldi, S. (Eds.), 2006. Lost Cities: From the Ancient World. Barnes \& Noble, New York

GS (Graduate School "Human Development in Landscape"), 2007. Full General Information. http://www.uni-kiel.de/landscapes/index3.shtml (Oct 22, 2012).

Hard, G., 1964. Geographie als Kunst: Zur Herkunft und Kritik eines Gedankens. Erdkunde, Archiv für wissenschaftliche Geographie 28, 336-341.

Hard, G., 1995. Szientifische und ästhetische Erfahrung in der Geographie. Die verborgene Ästhetik einer Wissenschaft. In: Werlen, B., Wälti, S. (Eds.), Kulturen und Raum. Rüegger, Chur, pp. 45-64.

Heard, G.W., Scroggie, M.P., Malone, B.S., 2012. Classical metapopulation theory as a useful paradigm for the conservation of an endangered amphibian. Biologica Conservation 148, 156-166.

Humboldt, A.v., 1849. Ansichten der Natur, 3rd revised and augmented edition, vol. 2. J. G. Cotta'scher Verlag, Stuttgart und Tübingen (Reprint: Eichborn, Frankfurt am Main, 2004).

IOM (International Organization for Migration) (Ed.), 2011. Intersessional Workshop on Climate Change, Environmental Degradation and Migration. International Dialogue on Migration 2011: Final Report. http://www.iom.int/jahia/webdav/ shared/shared/mainsite/microsites/IDM/workshops/climate-change-2011/ background_paper.pdf.

Jankuhn, H., 1977. Einführung in die Siedlungsarchäologie. De Gruyter, Berlin, New York.

Jahnkuhn, H., 1979. Siedlungsarchäologie als Forschungsmethode. In: Jahnkuhn, H., Wenskus, R. (Eds.), Geschichtswissenschaft und Archäologie. Untersuchungen zur Siedlungs-, Wirtschafts- und Kirchengeschichte. Thorbecke, Sigmaringen, pp. 19-43.

Janssen, W., 1988. Genetische Siedlungsforschung in der Bundesrepublik Deutschland aus der Sicht der Siedlungsarchäologie. In: Fehn, K. (Ed.), Genetische Siedlungsforschung in Mitteleuropa und seinen Nachbarräumen, vol. 1. Siedlungsforschung, Bonn, pp. 25-66.

Kant, I., 1783. Prolegomena zu einer jeden künftigen Metaphysik, die als Wissenschaft wird auftreten können. Hartknoch, Riga.

Kaplan, J.O., Krumhardt, K.M., Ellis, E.C., Ruddiman, W.F., Lemmen, C. Goldewijk, K.K., 2011. Holocene carbon emissions as a result of anthropogenic land cover change. The Holocene 21 (5), 775-791. http://dx.doi.org/10.1177/ 0959683610386983.

Kluiving, S., Guttmann-Bond, E. (Eds.), 2012. Landscape Archaeology between Art and Science. From a Multi- to an Interdisciplinary Approach. Amsterdam University Press, Amsterdam.

Kluiving, S., et al., 2012. LAC 2010: 1st international conference on landscape archaeology. Quaternary International 251.

Kossack, G., 1999. Prähistorische Archäologie in Deutschland im Wandel der geistigen und politischen Situation. Beck, München.

Kossinna, G., 1911. Die Herkunft der Germanen. Zur Methode der Siedlungsarchäologie. Kabitzsch, Würzburg.
Kwa, C., 2005. Alexander von Humboldt's invention of the natural landscape. The European Legacy 10, 149-162.

Lang, F., 2002. Klassische Archäologie. Francke, Tübingen.

Launaro, A., 2004. Concerning landscapes. Agri Centuriati. An International Journal of Landscape Archaeology 1, 31-41.

Levin, S.A., 1992. The problem of pattern and scale in ecology. Ecology 73, 1943-1967.

Lovejoy, A.O., 2009. The Great Chain of Being: a Study of the History of an Idea. Transaction, New Brunswick (original: Harvard University Press, Cambridge, Mass., 1936).

Lüning, J., 1997. Landschaftsarchäologie in Deutschland - Ein Programm. Archäologisches Nachrichtenblatt 2, 277-285.

Lyell, C., 1830. Principles of Geology. John Murray, Albemarle-Street, London.

May, R.M., 1988. How many species are there on earth? Science 241 (4872), 14411449.

Meier, T., 2012. In: Kluiving, Guttmann-Bond (Eds.), “Landscape”, “environment” and a Vision of Interdisciplinarity, pp. 503-514.

Meyers, R.A., 2009. Encyclopedia of Complexity and Systems Science. Springer, New York.

Morigi, A., 2009. Landscape archaeology e topografia Antica. In: Coralini, A. (Ed.), Vesuviana Vesuviana. Archeologie a confronto. Ante Quem, Bologna, pp. 365-378.

Odum, H.T., 1994. Ecological and General Systems. University Press of Colorado, Niwot.

OED (Oxford English Dictionary Online), 1989ff. Oxford University Press, Oxford. http://www.oed.com

Passarge, S., 1919. Beschreibende Landschaftskunde. Friedrichsen, Hamburg.

Passarge, S., 1921. Aufgaben und Methoden der vergleichenden Landschaftskunde. Reimer, Berlin.

Pinkerton, K.E., Joad, J.P., 2006. Influence of air pollution on respiratory health during perinatal development. Clinical and Experimental Pharmacology and Physiology 33 (3), 269-272.

Quilici, L., Quilici Gigli, S., 2004. Introduzione alla topografia antica. Il mulino, Bologna.

Ritter, J., 1974. Landschaft. Zur Funktion des Ästhetischen in der modernen Gesellschaft. In: Ritter, J. (Ed.), Subjektivität. Sechs Aufsätze. Suhrkamp, Frankfurt A. M, pp. 141-163.

Salvagni, I., Fratarcangeli, M. (Eds.), 2012. Oltre Roma: nei Colli Albani e Prenestini al tempo del Grand Tour. De Luca Editori d'Arte, Roma.

Santoro Bianchi, S., 1998. Archeologia del paesaggio: alcune riflessioni sui più recenti sviluppi metodologici in Italia. In: Campanati, R.F. (Ed.), XLIII Corso di Cultura sull'arte Ravennate e bizantina, Seminario internazionale di studi sul tema: "Richerche di Archeologia e Topografia" in memoria del Prof. Nereo Alfieri; Ravenna, 22-26 marzo 1997, pp. 817-838.

Schenk, W., 2001. Landschaft. In: Beck, H., Geuenich, D., Steuer, H. (Eds.), Reallexikon der Germanischen Altertumskunde. Established by J. Hoops. Kleinere Götter - Landschaftsarchäologie, vol. 17. 2nd Completely New and Intensely Augmented Edition. De Gruyter, Berlin, pp. 617-630.

Simmel, G., 1913. Philosophie der Landschaft. Die Güldenkammer 3, 635-644.

Smolla, G., 1979/80. Das Kossinna-Syndrom. Fundberichte Hessen 19/20, pp. 1-9.

Snodgrass, A., 2009. Archäologie in den angelsächsischen Ländern: Im Westen was Neues? In: Borbein, A.H., Hölscher, T., Zanker, P. (Eds.), Klassische Archäologie. Eine Einführung, second ed. Reimer, Berlin, pp. 347-363.

Steiner, N.C., Köhler, W., 2003. Effects of landscape patterns on species richness-a modelling approach. Agriculture, Ecosystems \& Environment 98, 353-361.

Teichmann, M., 2010. Zur Rolle und Perspektive der Landschaftsarchäologie in der (deutschen) Klassischen Archäologie: Eine Standortbestimmung im internationalen Kontext. Hephaistos, Kritische Zeitschrift zur Theorie und Praxis der Archäologie und angrenzender Wissenschaften. New Approaches in Classical Archaeology and Related Fields 27, 127-138.

Thomas, J., 1991. Rethinking the Neolithic. New Studies in Archaeology. Cambridge University Press, Cambridge and New York.

Ticktin, T., 2005. Applying a metapopulation framework to the management and conservation of a non-timber forest species. Forest Ecology and Management 206, 249-261.

Tylor, E., 1924. Primitive Culture. Brentano's, New York (Original: Murray, London, 1871).

Waldhardt, R., 2003. Biodiversity and landscape-summary, conclusions and perspectives. Agriculture, Ecosystems \& Environment 98, 305-309.

Witcher, R., 1999. GIS and landscapes of perception. In: Gillings, M., Mattingly, D., van Dalen, J. (Eds.), The Archaeology of Mediterranean Landscapes, Geographical Information Systems and Landscape Archaeology, vol. 3. Oxbow, Oxford, pp. 13-22.

Wuketis, F.E., 2010. Bild und evolution. In: Sachs-Hombach, K. (Ed.), Bildtheorien: Anthropologische und kulturelle Grundlagen des Visualistic Turn. Suhrkamp, Frankfurt am Main, pp. 17-30.

Wuttmann, M., Marchand, S., 2005. Égypte. In: Briant, P., Bouchariat, R. (Eds.), L'archéologie de l'empire achéménide. Persika 6. De Boccard, Paris, pp. 97-128.

Zalasiewicz, J., et al., 2010. The new world of the anthropocene. Environment Science \& Technology 44 (7), 2228-2231. http://dx.doi.org/10.1021/es903118j. 